This is an Open Access article, distributed under the terms of the Creative Commons Attribution licence (https://creativecommons.org/licenses/by/4.0/), which permits unrestricted re-use, distribution, and reproduction in any medium, provided the original work is properly cited.

\title{
Mummification in the Mesolithic: New Approaches to Old Photo Documentation Reveal Previously Unknown Mortuary Practices in the Sado Valley, Portugal
}

\author{
Rita Peyroteo-Stjerna ${ }^{1 *}$ (i), Liv Nilsson Stutz ${ }^{2}$ (†), \\ Hayley Louise Mickleburgh ${ }^{2}$ (i) and JoÃo Luís Cardoso ${ }^{3}$ \\ ${ }^{1}$ Uppsala University, Sweden \\ ${ }^{2}$ Linnaeus University, Växjö, Sweden \\ ${ }^{3}$ Open University, Lisbon, Portugal \\ *Corresponding author: Rita Peyroteo-Stjerna email: rita.peyroteo.stjerna@ebc.uu.se
}

Recently rediscovered photographs of the remains of thirteen individuals buried in the Sado Valley Mesolithic shell middens of Poças de S. Bento and Arapouco, excavated in 1960 and 1962, show the potential of revisiting excavation archives with new methods. The analysis, which applies the principles of archaeothanatology and is enriched by experimental taphonomic research, confirmed details concerning the treatment of the dead body and provided new insights into the use of burial spaces. Some bodies may have been mummified prior to burial, a phenomenon possibly linked to their curation and transport, highlighting the significance of both the body and the burial place in Mesolithic south-western Portugal.

Keywords: Mesolithic, burial, pre-burial mortuary practice, archaeothanatology, mummification, experimental taphonomy

\section{INTRODUCTION}

A few years ago, three rolls of film from the excavation of two Mesolithic burial sites in the Sado Valley in south-western Portugal resurfaced. Both sites, Arapouco and Poças de S. Bento, were excavated in the 1960s and more recently in the 1980 s and 2010s (Arnaud, 1989; Larsson, 1996; Arias et al., 2021), and most of their human burials have been studied and published (Cunha \& Umbelino, 1997; Peyroteo-Stjerna, 2016). The photographs of burials excavated in 1960 and 1962 were, however, missing, and the documentation was incomplete. The rediscovery of these photographs thus provided a unique opportunity to add to our knowledge of Mesolithic mortuary practices.

In this study, new interpretative resources are brought to bear on old documentation, especially the principles of archaeothanatology (Duday et al., 1990; Duday, 2009). Archaeothanatology is a taphonomically based approach to documenting and analysing human remains in archaeological contexts that relies on combining observations of the spatial distribution of the 
bones in the field with knowledge about how the human body decomposes after death. This approach offers not only an interpretative framework, but also a methodology for excavating and recording burials. Since the graves studied here were not recorded following an archaeothanatological protocol, we do not have all the information an archaeothanatological analysis would require; nonetheless, earlier studies that have applied archaeothanatology to older excavations have demonstrated that new and detailed information can be gained even when recording in the field was not carried out within an archaeothanatological framework (Nilsson Stutz, 2003, 2009; Peyroteo-Stjerna, 2016; Tõrv, 2018). These studies have also shown the potential of archaeothanatology for illuminating aspects of ritual practice and the handling of the body. Furthermore, our study combines archaeothanatological analysis with insights from experimental taphonomic research, thus adding a new dimension to our understanding of Mesolithic mortuary practices. Here we present what we believe to be evidence for intentional mummification and reflect on attitudes to the body and the handling of the dead, including their transport to significant places in the landscape.

\section{History of the Documentation}

The recently rediscovered photographs document the human burials excavated in 1960 at Poças S. de Bento and in 1962 at Arapouco, two of six Late Mesolithic shell middens with human skeletal remains known in the Sado Valley (Figure 1).

The first and largest excavations in the Sado middens were carried out by the National Museum of Archaeology, Lisbon, between 1958 and 1964, recovering more than 100 skeletons dating to between 8150 and $7000 \mathrm{cal} \mathrm{вP} \mathrm{(Peyroteo-Stjerna,} \mathrm{2021).}$
Despite multiple attempts, only two skeletons from Arapouco (1962, 2A) and S. Bento (2013, XIV) have provided reliable radiocarbon measurements, ranging between 8150 and $7900 \mathrm{cal} \mathrm{BP} \mathrm{(Cunha} \mathrm{\&}$ Umbelino, 2001; López-Dóriga et al., 2016; Peyroteo-Stjerna, 2016, 2021), indicating that burial activity at the two sites was broadly contemporaneous.

Most of the archaeological material and documentation available are curated at the National Museum of Archaeology, but some photographs, site plans, and field drawings were missing from the archive (Cunha \& Umbelino, 1997; PeyroteoStjerna, 2016: 227). The rolls of undeveloped photographic films were identified by one of us (Cardoso) in the personal archive of archaeologist Manuel Farinha dos Santos (1923-2001). Handwritten notes on the original film packaging indicate that the photographs are from the shell midden sites of Arapouco 1962 (one film) and Poças de S. Bento 1960 (two films). Farinha dos Santos collaborated with the National Museum and, although he did not work at these sites, part of his research was in this region (Santos et al., 1974; Cardoso, 2013).

We attributed Arapouco's photographs to the 1962 excavation season (ARA1962) by comparing the numbering of the burials, observing similarities in the concentration of shells and the preservation of the skeletal elements, and matching the spatial distribution of the burials. Arapouco was excavated in 1961 and 1962, but the site plan in the museum's archives shows only the areas excavated in 1961 and there is no information about the stratigraphy or precise location of the human burials (Peyroteo-Stjerna, 2016: 227). The minimum number of individuals curated at the museum is thirty-two, including six subadults and twenty-six adults (Cunha \& Umbelino, 1997). The museum's archives contain photographs 

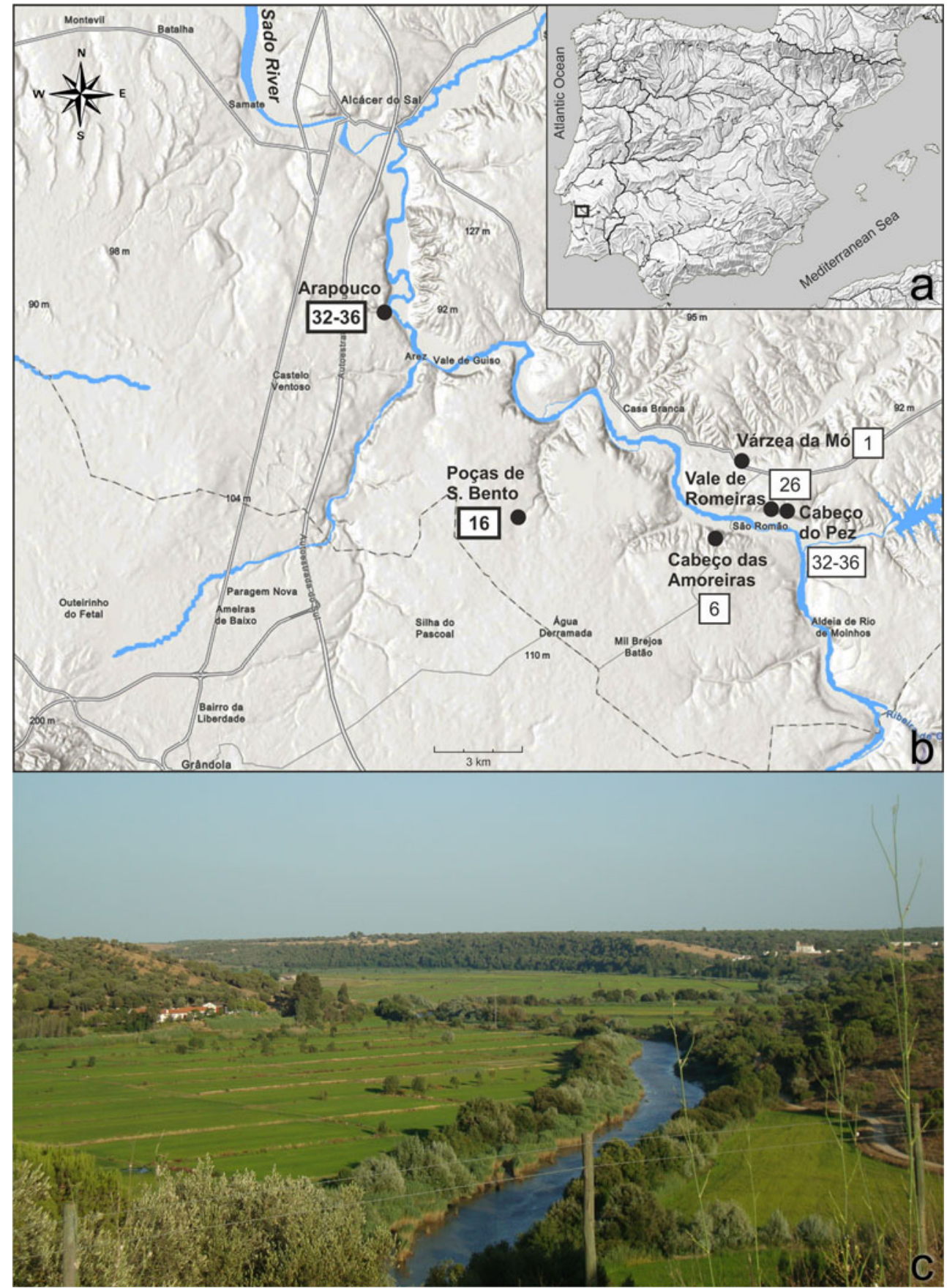

Figure 1. a) The Iberian Peninsula and location of the shell middens of the Sado Valley, Portugal. b) Arapouco and Poças de S. Bento, with minimum number of individuals excavated in each site (Cunha E Umbelino, 1997; Diniz et al., 2014). c) View from Arapouco towards the south-east of the Sado and its alluvial plain. 


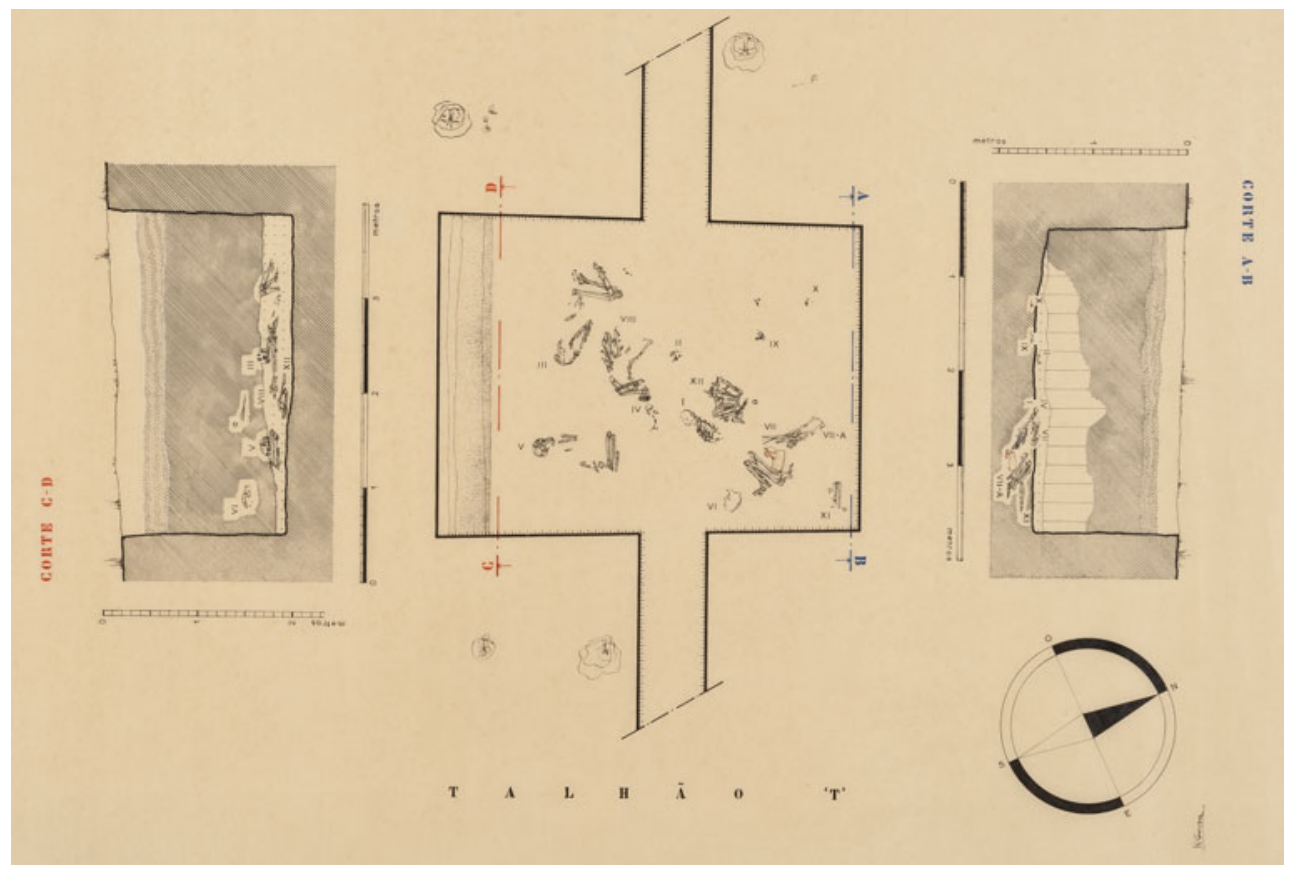

Figure 2. Poças de S. Bento, site plan A119 by Dario de Sousa in the archive of the National Museum of Archaeology, Lisbon. Area with the remains of twelve individuals excavated in 1960. Scale 1:20. Photograph by J. P. Ruas.

from both field seasons, but the only graphic record of human remains was a set of photographs from 1961 documenting fifteen individuals. The 1962 photographs in the museum's archives do not show any human remains (Peyroteo-Stjerna, 2016: 227). This gap has now been filled. Finally, two burials from Arapouco preserved in paraffin blocks at the museum could be identified as identical to those in the photographs. Two of the photographed graves are not numbered but are nevertheless attributed to Arapouco as they were on the same film roll and no other shell midden was being excavated in 1962 .

The photographs on the two other rolls of film were identified as documenting the 1960 field season at Poças de S. Bento (PSB1960). S. Bento was excavated in 1960 (Figure 2) and 1964, and further investigated in the 1980s and 2010s (Arnaud, 1989; Larsson, 1996; Arias et al., 2021). The graphic documentation at the National Museum consists of two site plans showing all burials in the excavation and several individual drawings of the human remains (individuals I to XII). Previous analyses of the burials were limited by the poor quality of the photographs available in the museum's archive and the fragmentary nature of the human remains (Peyroteo-Stjerna, 2016: 75). We were able to confirm the provenance of the burials in the photographs as being from Poças de S. Bento 1960's excavation by comparing them with the existing documentation in the museum, and by establishing similarities in the sandy basal layer of the graves and their similar preservation.

\section{Analysis}

Our analysis focused on reconstructing the distribution of the graves on the sites, and 


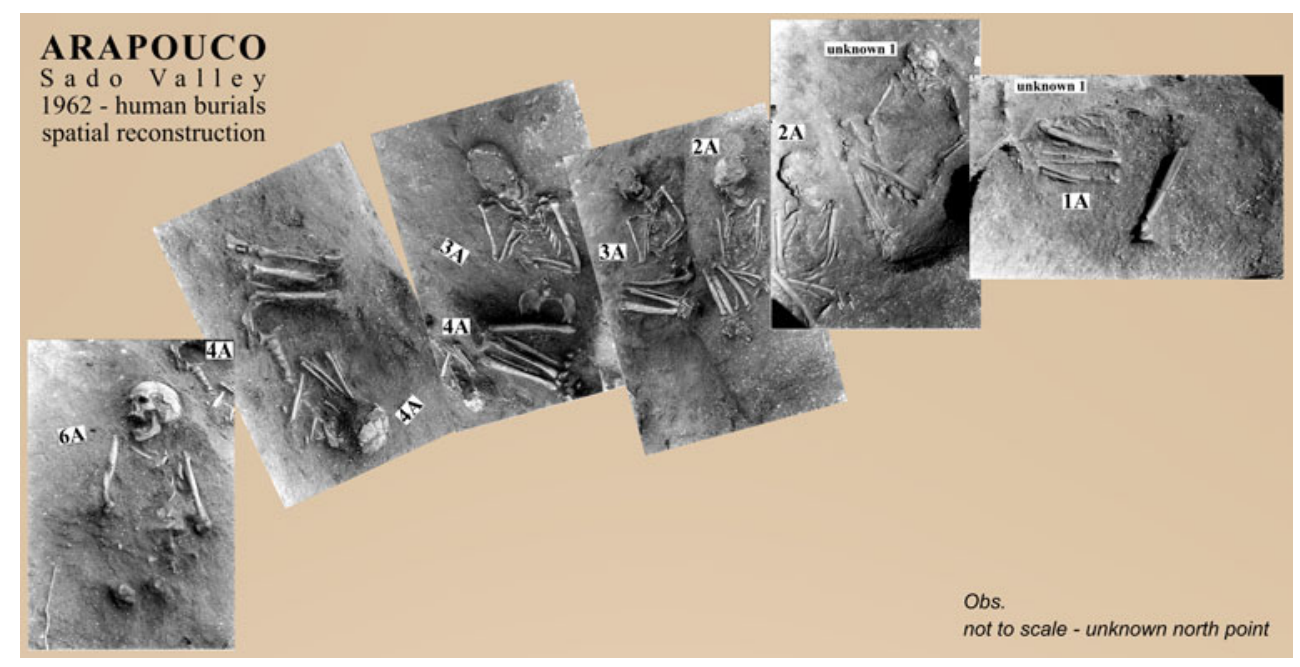

Figure 3. Arapouco, 1962. Reconstruction of the spatial distribution of the burials based on the new photographic documentation showing graves placed in close proximity.

on closely examining each burial, applying an archaeothanatological approach that in selected cases was complemented with insights from experimental taphonomic research. The new set of photographs was digitized and can be found as Figures S1S38 in the Supplementary Material.

\section{Spatial reconstruction}

Most photographs from Arapouco show several individuals and this makes it possible to reconstruct the spatial arrangement of all individuals, except for unknown 2 and 3 (Figure 3). This is important because there are no site plans for Arapouco showing the burials in situ. As in other shell middens in the Sado Valley, the excavation photographs show that the burials were placed close to each other, with little disturbance of previous burials, suggesting knowledge of prior burials (PeyroteoStjerna, 2016: 474).

For S. Bento, drawings from the museum's archives document the layout of the burials. Here we present a reconstruction based on the drawings and the new photographs (Figure 4). While the burials were closely spaced, with little disturbance of previous burials, the new photographs show that some burial spaces clearly overlap and the same space was reused. The deposition of PSB1960, III in the same space as grave VIII entailed the disturbance and partial removal of the remains of VIII to deposit individual III. This behaviour, known in archaeothanatology as reduction (Duday, 2009: 72), was previously unclear when only the drawing was available (Figure 4, Figure S26).

\section{Archaeothanatological analysis}

Archaeothanatological analysis was carried out on the thirteen individuals (eight from ARA1962 and five from PSB1960) documented in the recently rediscovered photographs. The analysis seeks to identify the effects of natural processes of decomposition on the deposit in order to reconstruct the effects of human practices (Duday, 2009). Ideally, archaeothanatology relies on detailed field observations of the precise position, orientation, and dip of 


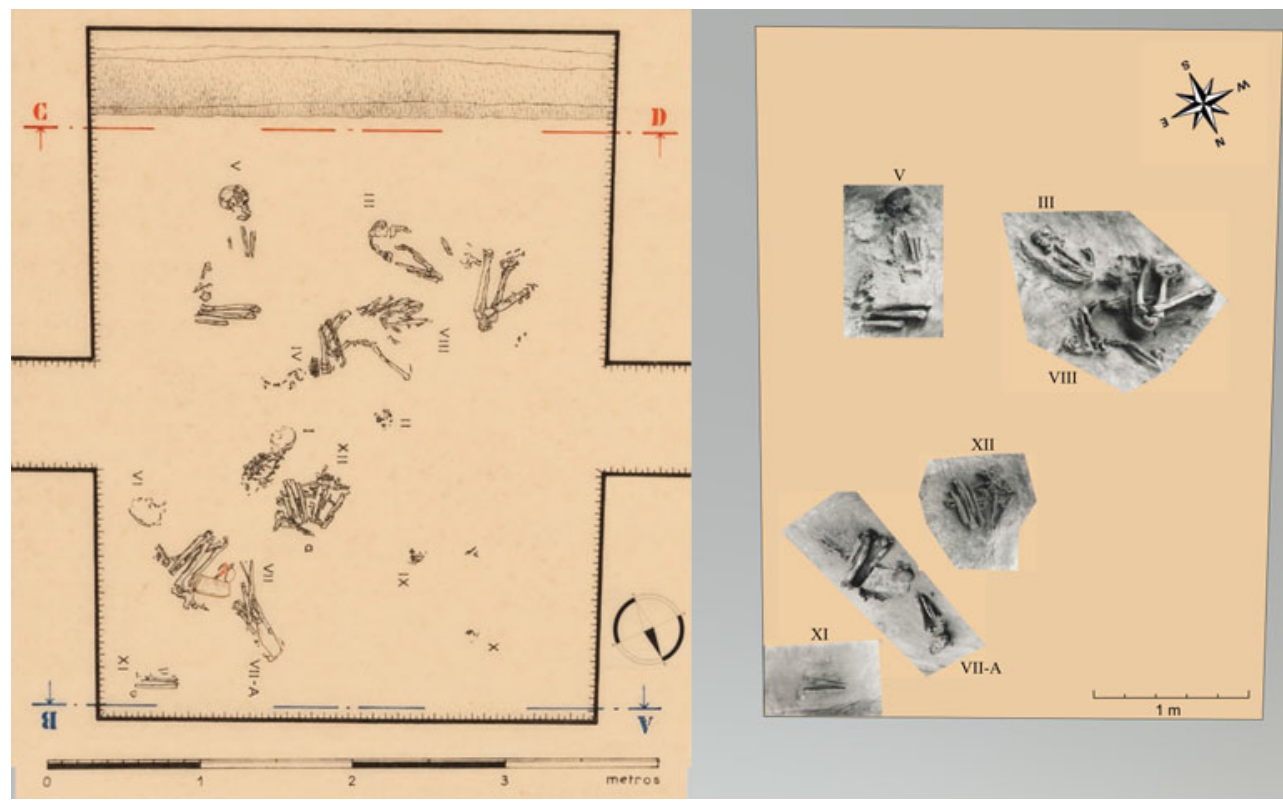

Figure 4. Poças de S. Bento, 1960. Reconstruction of the spatial distribution of the burials based on the site plan at the National Museum of Archaeology, Lisbon, and new photographic documentation. Photograph by J. P. Ruas.

each bone in the field, documented in three-dimensional coordinates, but this was obviously not available here.

The photographs themselves also have limitations. In part these are related to the norms of photographic documentation at the time, which often meant that relatively few shots were taken. While most photographs show a general view of one or several individuals, providing important information about the relative position of the burials, the lack of close-up views makes it difficult to identify diagnostic skeletal elements. Most photographs were taken from oblique angles, resulting in distortion of the distances in the images and in partially obscuring some of the skeletal elements. In addition, they do not record the various stages of the excavation, which may be related to the fact that, at the time, photographs were mostly considered to be documenting scientific evidence and rarely documented investigative processes. The photographs are monochrome, sometimes with overexposure or high contrast levels resulting in dark portions in the images, making it difficult to distinguish the sediments and sometimes the position of the bones. In sum, our photographs do not always contain diagnostic elements which would allow identification of precise spatial relationships between specific bones and joints.

While not compensating for all these issues (for example we did not manipulate the photographs to rectify them), we were able to add information from existing field drawings and site plans (Poças de $\mathrm{S}$. Bento) and from the analysis of the human remains preserved in two blocks of paraffin wax from Arapouco (ARA1962, $1 \mathrm{~A}$ and 3A). In two cases (PSB1960, unknown and $\mathrm{XI})$, the preservation was so poor that even a limited analysis was impossible (see Table S1). While these constraints introduce a significant uncertainty, it was still possible to obtain sufficient data to support our observations 
regarding the treatment of the dead and determine the burial process at the two sites as well as identify previously undocumented pre-burial practices. Further details are available in Tables S2-S4 in the Supplementary Material.

The analysis of the nature of the deposits suggests that at Arapouco and S. Bento the cadavers were placed in graves before their labile joints decomposed. In seven cases diagnostic features are poorly preserved, but the overall position of the skeletal elements strongly suggests that the bodies were deposited while still retaining their general anatomical integrity supporting the interpretation of primary burial (Table S2).

For the space of decomposition, our analysis confirms a general pattern of filled spaces at both sites (Table S2). The cadavers were covered immediately after being placed in the feature, and decomposition took place in this sediment-filled environment. In four cases, the results are unclear due to poor preservation. In most cases, the movement of the bones was limited, suggesting that the space of decomposition was filled and that the sediment could penetrate immediately. One case suggests mixed decomposition spaces (ARA1962, unknown 2).

The position of the body differed between the two sites. At Arapouco, the most common initial position of the cadaver in the feature (Table S3) was on its back $(n=6)$ or rotated to the side $(n=$ 2 ), with the lower limbs in flexion or hyperflexion, placed towards the upper body and with the feet forced towards the buttocks (Figure 5).

This constricted position results in a phenomenon referred to as 'clumping', previously observed in the Sado burial sites (Peyroteo-Stjerna, 2016: 444) and interpreted as resulting from hypercontraction of the body during decomposition in situ by the progressive closure of the angles between the anatomical segments. At Arapouco, four skeletons present this pattern. At S. Bento, most cadavers were placed in the same general position with the limbs flexed in front of the body, but here three bodies were placed on the right side and one on the left. Only one of the five individuals analysed was placed on its back. In some cases, the remains show an extreme degree of flexion (ARA1962, 2A, unknown 2 and 3; PSB1960, XII) indicating that additional constraining elements, such as a tight wrapping (full wrapping or simply binding with ropes or bandages) was probably applied to the body. Except for individual XII, the S. Bento burials do not show any indications of 'clumping', which may be due to their position on their side rather than on their back.

The analysis of the shape of the graves (Table S4) suggests that the bodies were placed in small pits dug into the ground and that the limits of the grave constrained the arrangement of the body. The lateral pressures and wall effects observed on the skeletons indicate that, in most cases, the shape and size of the pit was sufficient to contain the body, providing lateral support and preventing the collapse of the skeletal elements during decomposition. The base of the grave tended to be irregular and sloping downwards from the upper to the lower part of the body, a shape referred to as a cuvette, common in the Portuguese Mesolithic (Peyroteo-Stjerna, 2016: 445). The cuvette phenomenon is especially visible in Arapouco and probably linked to the position of the body on its back with the head raised in relation to the trunk and/or the head's flexion and collapse forwards and downwards (e.g. burials $2 \mathrm{~A}, 3 \mathrm{~A}$, 4A, 6A). The fragmented state of the material precludes detailed observations in the region of the ribs and sacrum, whose rotations during decomposition could clarify aspects of the original position of the body in the feature. 


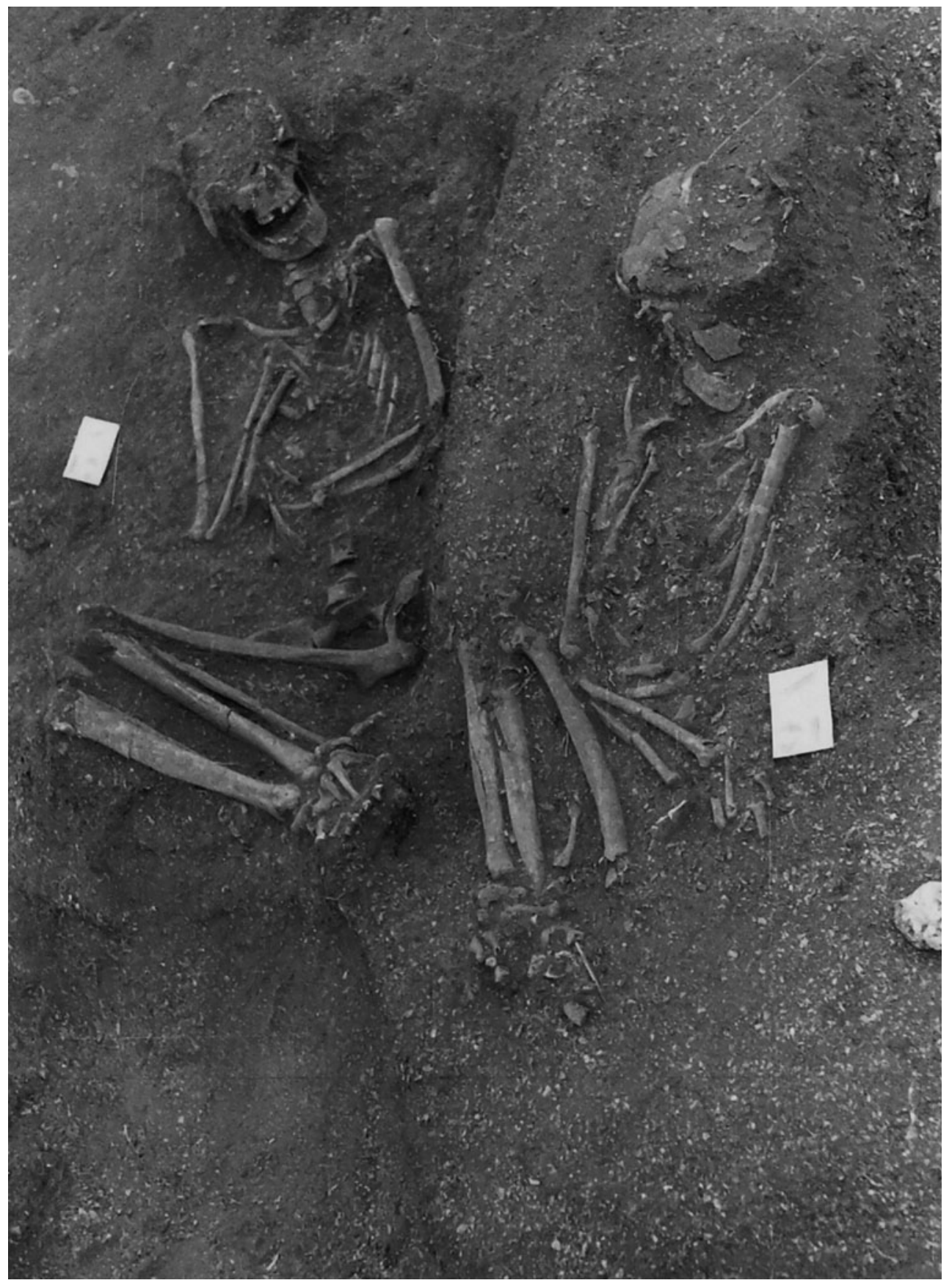

Figure 5. Arapouco 1962. Skeleton $3 A$ is visible on the left of the photograph, lying on the right side of skeleton $2 A$. These burials illustrate several traits common to the Sado Valley burials during the Mesolithic.

The graves are usually quite constricted, but burial PSB1960, VII-A (Figure 6) is an exception. Here the body was placed on the right side, with the upper limbs flexed in front of the body, and the lower limbs moderately flexed, indicating a 


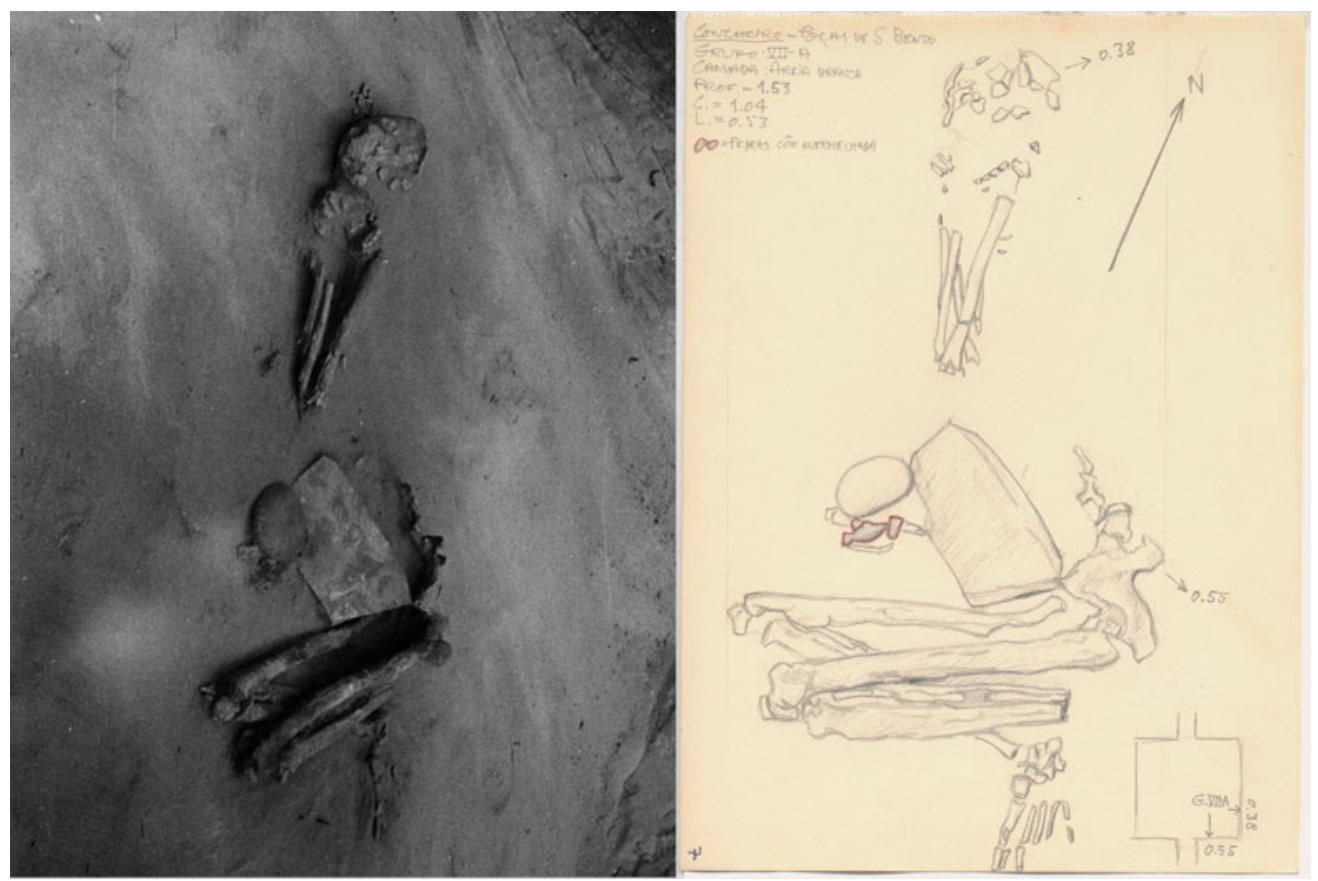

Figure 6. Poças de S. Bento 1960, skeleton VII-A. The new photograph shows two stone objects in the grave, never described and only previously documented on a drawing at the National Museum of Archaeology, Lisbon. The drawing seems to have been made after the round stone covering the red coloured stones had been lifted, as noted on the top left of the drawing, pedras côr avermelhada (reddish coloured stones).

primary burial in a filled space. While the left portion of the os coxae was maintained in anatomical position, suggesting significant lateral support at this level from the wall of the burial pit, the position of the right foot in extension suggests that the pit was wide enough to contain the body without exerting the pressure on the skeletal elements otherwise typical at the site. In addition, the grave contained a stone slab and a large round stone, both placed in front of the abdomen. Such objects have not been observed in any other grave in the Sado middens, which typically contain only human remains (PeyroteoStjerna, 2016). While these elements were already known from a drawing in the museum's archives, the new photographs offer more detail.

In sum, the two sites suggest similar mortuary practices characterized by primary burial in contracted positions restricted by pits dug into the ground and immediately backfilled. The placement of the bodies at Arapouco, mostly on their back, differs from that at S. Bento, where the bodies are on their side. These findings align with results from the analysis of burials previously studied from Arapouco and other Mesolithic burial sites in the Sado Valley (Peyroteo-Stjerna, 2016: 443-47).

\section{Evidence of mummification}

While most of the burials conform to what we expect from Mesolithic burials in the Sado Valley, two stand out for the unusual position of the remains: one at Arapouco (ARA1962, unknown 3) and one at Poças de S. Bento (PSB1960, XII), suggesting complex pre-burial treatment of the body. 


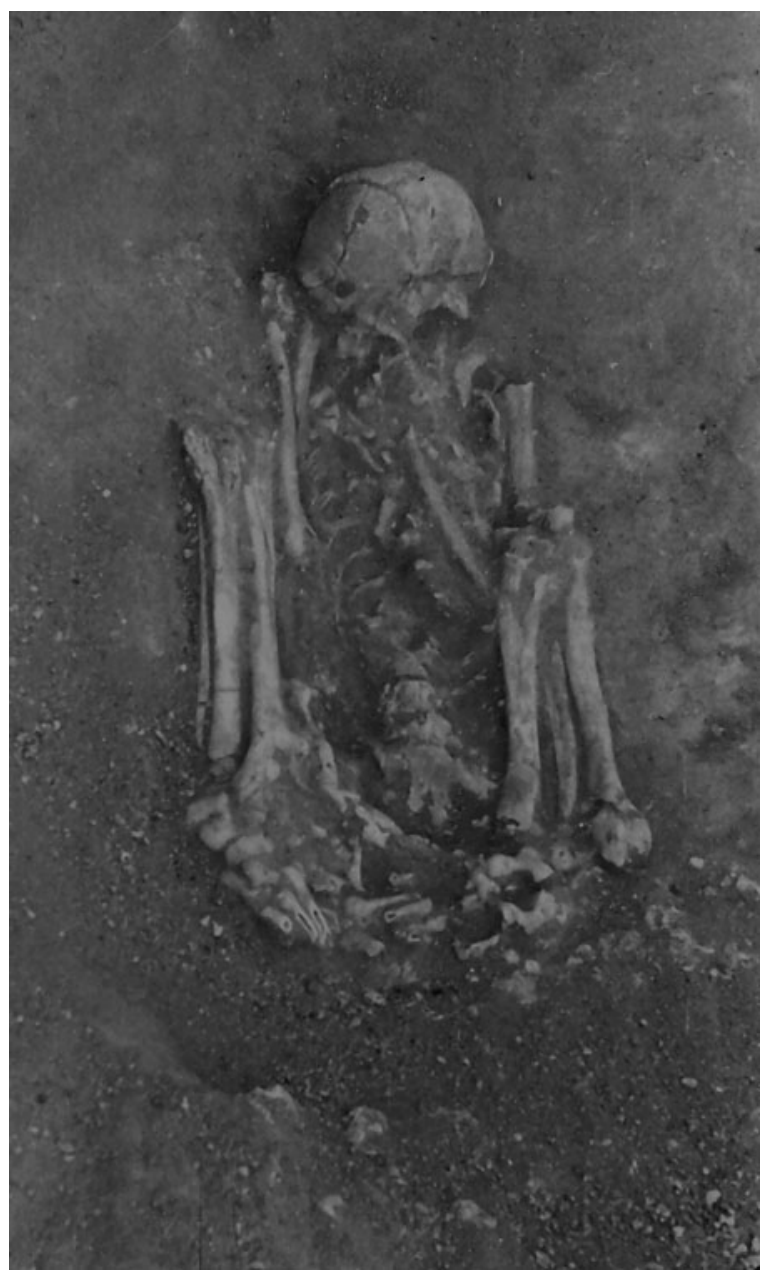

Figure 7. Arapouco 1962, skeleton unknown 3 shares the basic characteristics of all the burials at the site but was placed in a hyperflexed position which in combination with the lack of movement of the bones in the feature suggests the body was prepared and desiccated before burial.

ARA1962, unknown 3, consists of the remains of an adult, lying on its back with the limbs in extreme flexion in front of the body (Figure 7). The head was rotated to the left. The right upper limb was strongly projected upwards and hyperflexed at the elbow, with the forearm lying immediately to the lateral side of the upper arm. The left upper limb was flexed at the elbow and rotated inwards, bringing the forearm diagonally across the upper portion of the thoracic cage, and the hand resting in front of the right side of the chest/right shoulder. Both upper limbs were subjected to a very strong bilateral pressure, which forced them inward towards the thoracic cage. The thoracic cage is less clear on the photograph but also appears to have had pressure from both sides. The lower limbs were hyperflexed at the hip and knee joints, bringing them up and to the sides of the thorax. They are rotated inwards, showing their lateral sides, and bringing the feet immediately below the sacrum with the toes pointing medially. While there is a degree 
of collapse of the bones, there is no movement outside the original volume of the cadaver, which indicates a filled space.

Some of this lack of movement, especially at the feet, raises questions. This anatomical segment contains both labile (phalanges and metatarsals) and persistent (tarsals) articulations, but, even in a filled space, some of these bones, particularly those connected by labile articulations, would be expected to move during decomposition, given their position in an area so rich in soft tissue. The contracted position affecting all four limbs and the thoracic cage, and the unexpected lack of disarticulation of labile pedal phalanges, call for an explanation. An overall lateral pressure was exerted, and a general wall effect from all sides of the feature is visible in the alignment and bundling of the right upper limb and both lower limbs. This wall effect might correspond to the physical limits of the pit and could have been caused by an almost square burial pit or container. But the hyperflexion entails positioning the bones beyond the normal range of movement of a fully fleshed body and the maintenance of this position; these two aspects suggest that additional factors were at play. Decomposition of the body in situ would normally generate activity such as bloating followed by the creation of significant empty spaces within the initial volume of the body as soft tissue disappears. In filled primary burials, disarticulated bones, such as phalanges, have often moved into such empty spaces. For ARA1962, unknown 3, however, the areas of the feet (placed in front of the thighs, buttocks, and just below the abdomen) and the lower limbs show extreme flexion in combination with the surprising maintenance of labile articulations, indicating that the body was not placed in the grave as a fresh cadaver, but in a desiccated state, i.e. as a mummified corpse.
PSB1960, XII (Figure 8) is another case of hyperflexion. The position of the body in the grave appears extremely 'flattened', and very little sediment is present between overlying bones (see Figures S37 and S38). Given the incomplete documentation, the state of the labile joints cannot be ascertained. However, the position of the bones with extreme 'clumping' of the lower limbs, in combination with an overall lack of movement, resembles the pattern seen in ARA1962, unknown 3, suggesting that a similar form of preparation of the body (mummification?) before burial should be considered. An alternative hypothetical cause for the hyperflexion observed in this skeleton, i.e. (tight) wrapping of the fresh body and/or pressure from surrounding sediment, causing the intersegmental angles between the bones to close, is less likely. Indeed, the sandy sediment in which the remains were found would have rapidly penetrated voids created by the decay of the soft tissues in situ, and hence closing of the intersegmental angles would have been very limited. Moreover, wrapping materials, which may have protected the body from the influx of sediment, would have simultaneously allowed voids to form within the wrapping and movements to occur within this space as the soft tissues decomposed, leading to the disarticulation of joints. While the photographs do not show the state of articulation of some parts of the skeleton, the overall evidence suggests that PSB1960, XII may also be a case of mummification, albeit less clear.

Mummification can affect the sequence of disarticulation, preserving the otherwise labile articulations of the hands and feet. Persistence of labile joint connections, combined with disarticulation of the persistent joint connections, has been suggested by Maureille and Sellier (1996) as an important indicator of burial in a desiccated or mummified condition, but they note that certain features associated with 


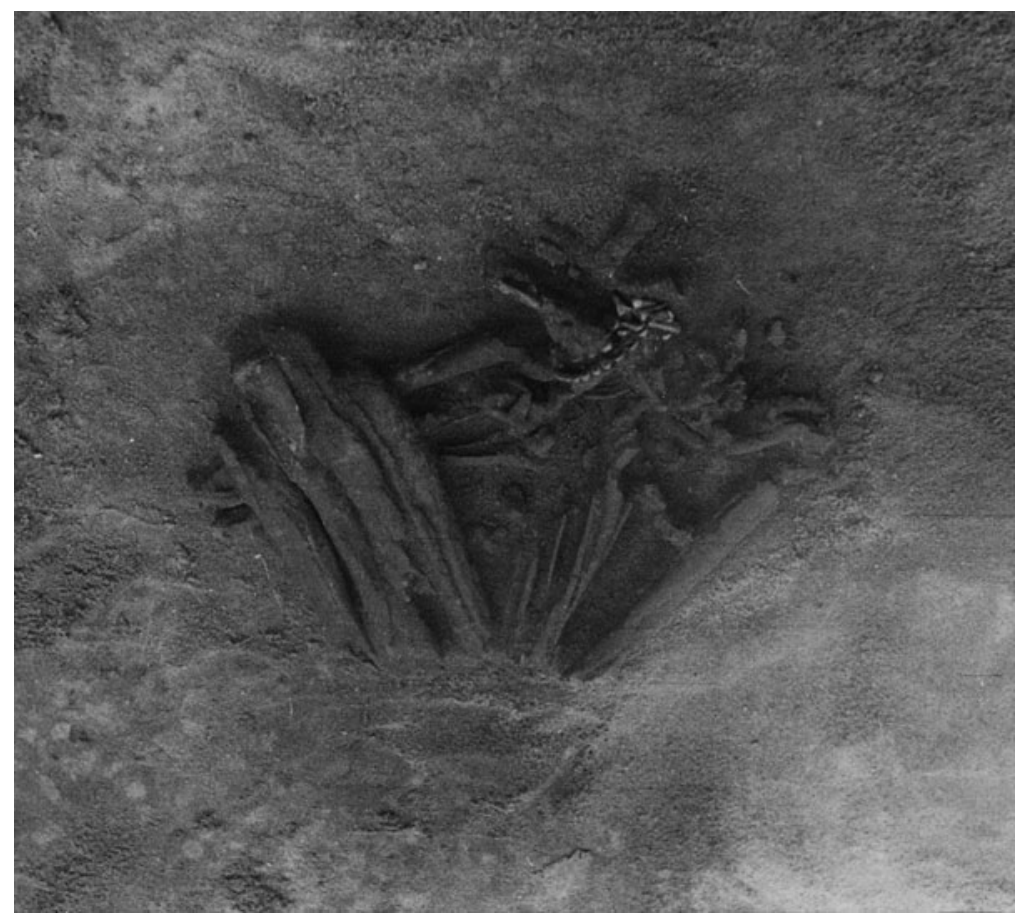

Figure 8. Poças de S. Bento 1960, skeleton XII. The extreme 'clumping' of the lower limbs may suggest the body was prepared and desiccated prior to burial.

burial in a mummified condition, such as the maintenance of the volume of the ribcage, are dependent on the properties of the surrounding sediment.

Desiccation of the soft tissues in mummified bodies can allow for much stronger flexion, since the range of movement increases when the volume of soft tissue is smaller. Hyperflexion of skeletons placed on their back with the lower limbs, and sometimes the upper limbs, hyperflexed at the knees and the pelvis (drawn toward the abdomen) has been documented in the Caribbean and interpreted to have resulted from burying a body in a desiccated or mummified state (Hoogland et al., 2001; Hoogland \& Hofman, 2013). In these cases, there is very little or no sediment present between the femur and tibia and fibula, or between the humerus and ulna and radius. Nonetheless, the articular connections are maintained in combination with the contracted position of the body with the lower limbs brought up in front of the body. An example in a Late Ceramic Age (dated to cal AD 1350-1450) burial at Kelbey's Ridge, Saba, in the Dutch Caribbean, is of an adult male with the remains of two children placed inside his ribcage (Hoogland \& Hofman, 2013: 460-61). Similar cases of mummification of bodies wrapped in a hammock or contained in a basket and placed near fire to cause desiccation have also been suggested for the Late Ceramic Age site of Anse à la Gourde, Guadeloupe (Hoogland \& Hofman, 2013: 457). While there are differences in mortuary practices between these contexts, the position of the lower limbs in combination with the maintenance of the labile articulations of the feet are remarkably similar.

Henri Duday (2009: 54) has noted that hyperflexion could result from natural 
decomposition processes in situ but the overall strict anatomical relation and articulation of the bones in the hyperflexed burial of ARA 1962, unknown 3 seems to indicate that there were no open spaces that formed within the original volume of the body through decomposition, reflected by the preserved articulations of labile elements, especially the phalanges. Decomposition of soft tissues with progressive infilling of surrounding sediment can be ruled out as an explanation for the movement of the forearm and leg bones in close superposition with very little sediment between them, as the initial (nonhyperflexed) position would be maintained by the infiltrating soil. If there was indeed no open space in the grave at any stage of decomposition (including space resulting from the decay of soft tissues), this contracted body position would only be possible if the remains were buried in the hyperflexed position observed.

Human decomposition experiments, conducted by one of us (Mickleburgh) at the Forensic Anthropology Research Facility at Texas State University between 2015 and 2021 on the burial of a supine flexed fresh body and a supine flexed naturally mummified body, were designed to investigate the association between hyperflexion and paradoxical disarticulation and mummification of the body. These experiments showed that in situ movement of bones due to the decomposition of soft tissue can occur in both fresh bodies with a normal volume of soft tissue around the bones and highly desiccated bodies with relatively little soft tissue around the bones.

Bone movement in these experiments was observed to be strongly associated with the soil type, and its potential to maintain open spaces in the grave for extended periods. Plant growth and the proliferation of fine roots throughout the grave also contributed to the maintenance of voids in the graves as well as to supporting small bones in a position of equilibrium. Disarticulation and movement of joints considered to be persistent, such as the ankles and the atlanto-occipital joint, was observed in both bodies. Closing of the intersegmental angles between the long bones of the lower limbs was observed in the fresh cadaver, confirming that the supine flexed body position can contribute to increased flexion. However, this movement was also associated with disarticulation at the level of the ankle (considered to be a persistent joint connection). The feet remained in supported (elevated) position in anatomical articulation, as the creation of open space by the loss of the soft tissue of the calves and thighs did not create a substantial void below the feet for them to move into.

The mummified body showed maintenance of the labile connections (with the exception of the left foot, right fibula, and mandible, which were disturbed by small animal activity), as well as bone movement mainly in the abdominal and thoracic areas, where decomposition of the dried soft tissues allowed the bones in these areas to settle downward into the grave. The left lower limb, which was flexed over the abdomen was thus able to move downwards with the left femur, coming to rest directly on the lumbar vertebrae and the femoral head disarticulating from the acetabulum. The ribcage volume was lost as the dried soft tissue decayed. The experiments demonstrate that open spaces can form, and bone movement can and will occur, in both fresh and mummified bodies upon burial, depending on the properties of the surrounding sediment and its ability to maintain secondary voids. These bone movements are associated in both cases with joint disconnection.

For hyperflexed positions to be present in a burial with preserved labile joint connections in unstable positions, the body 


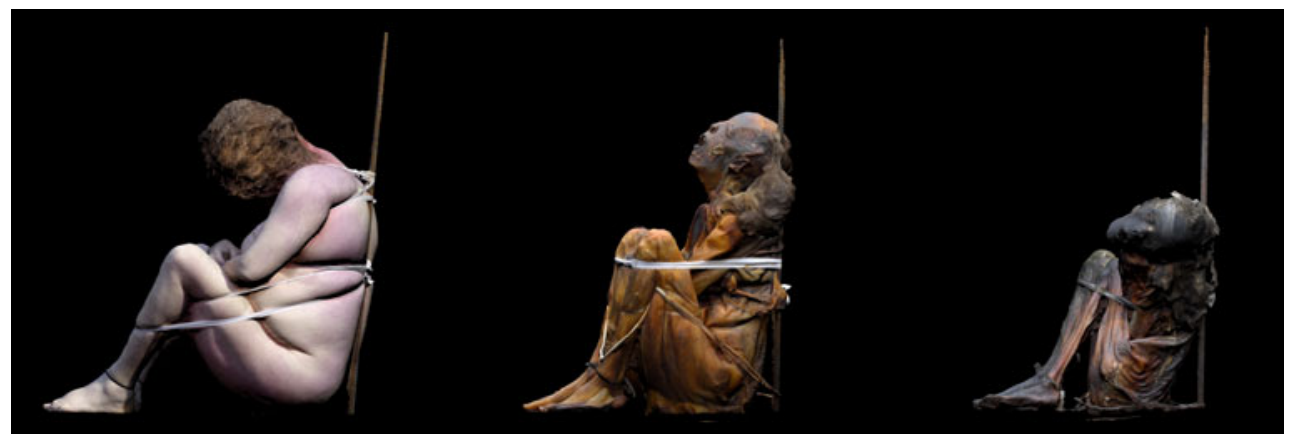

Figure 9. Reduction of the soft tissue volume during guided natural mummification. Left: fully fleshed body on day 1 of the experiment placed as tightly flexed as possible using bandages to maintain body position. Centre: reduced body volume and increased flexion of the body after three weeks, due to desiccation of the soft tissues and repeated tightening of the bandages. Right: further reduced body volume after seven months, due to continued desiccation of the soft tissues. The bandages were not further tightened after three weeks.

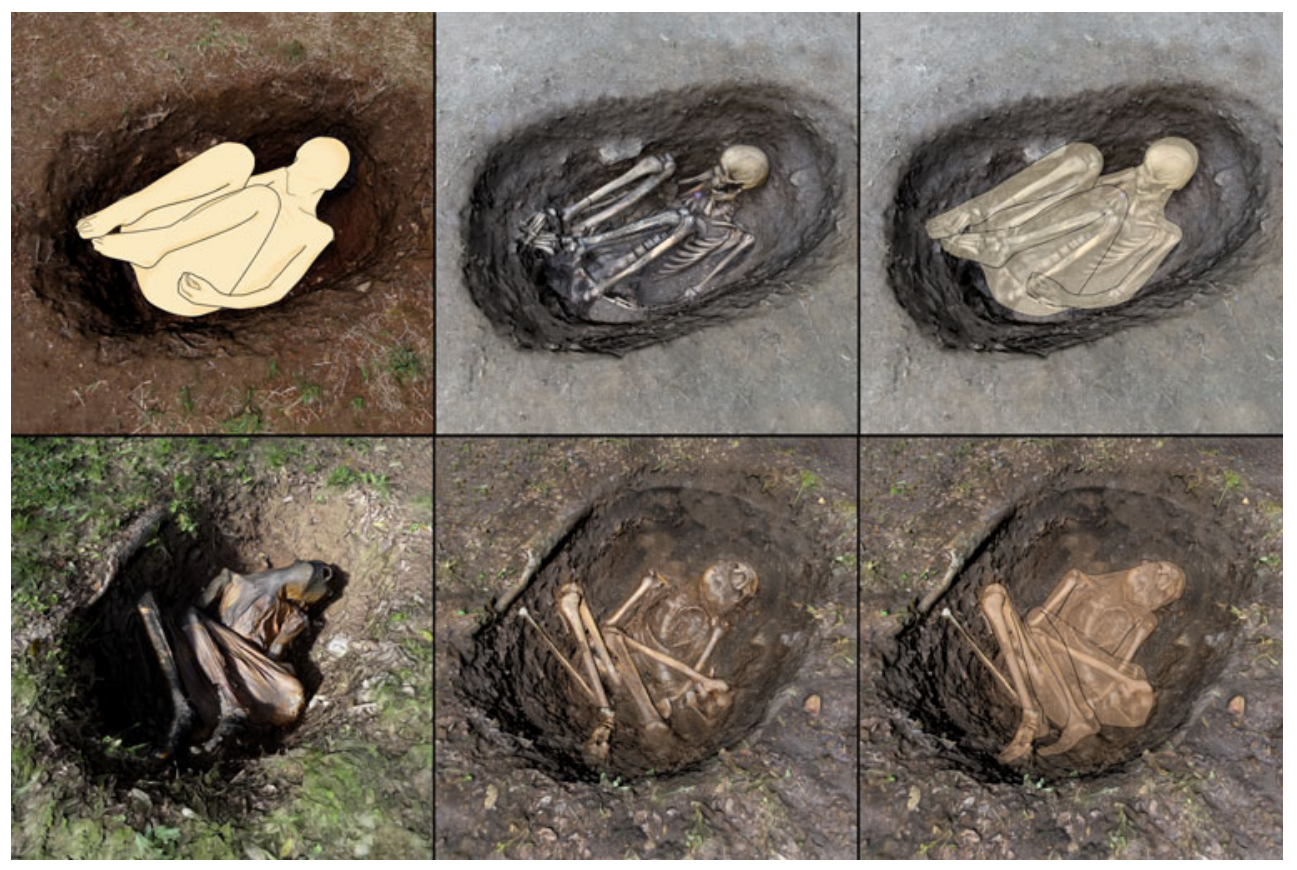

Figure 10. Top row: experimental burial of a fresh body in flexed supine position, unclothed, directly in the soil. Top left: initial body position of the freshly deceased individual. Top centre: position of the skeleton upon excavation after two years and two months. Top right: relationship between the initial body position and the final position of the bones. Bottom row: experimental burial of a desiccated body after seven months of guided natural mummification and trussing during the first three weeks. Bottom left: initial body position of the mummified individual. Bottom centre: position of the skeleton upon excavation after three years and two months. Bottom right: relationship between the initial body position and the final position of the bones. See extended description in the Supplementary Material. 
must have been initially buried in this hyperflexed position. The combination of hyperflexion throughout the body with a lack of disarticulation or evidence of in situ bone movement, as observed in Arapouco 1962, unknown 3, is therefore a strong taphonomic indicator of burial in a mummified condition. The position of unknown 3 could therefore be the product of a guided natural mummification process, in which tightening of bindings around the body (trussing) over time and reduction of the soft tissue volume created the hyperflexed position and at the same time supported the maintenance of the labile joints (Figure 9). While the precise taphonomic signature depends heavily on the soil properties in the burial environment, the burial of a fully fleshed supine flexed body would leave a different taphonomic signature than the burial of a hyperflexed supine mummified body. In soil types which maintain open spaces within the grave for extended periods, substantial movement and closing of the intersegmental angles is possible in burials of fresh, fully fleshed flexed bodies. In soils that rapidly infiltrate open spaces, the natural volume of the fleshed body and non-hyperflexed bone positions would be maintained. Delayed infilling with sediment in mummified burials can also allow bone movement, although it will be restricted to the areas of the mummified body that still have substantial volume (i.e. the abdomen and thorax). Rapid infilling in mummified burials would maintain the initial hyperflexed position of the body and prevent bone movement or disarticulation (Figure 10). At both Arapouco and S. Bento, all human burials were cut into the sandy base layers of the shell middens (Peyroteo-Stjerna, 2016: 475). Several good examples of rapid penetration of sediment are known at Arapouco, and an hourglass effect (Duday, 2009: 38) was often detected, indicating that fine sand could penetrate immediately and progressively fill the empty spaces created as soft tissue decayed, thus preventing the bones from collapsing.

\section{Discussion}

The archaeothanatological analysis of photographic and written documents at Arapouco and Poças de S. Bento has revealed evidence of mortuary practices that correspond to what we already know about Mesolithic burials in Portugal, with a slight variation in the position of the body between the two sites perhaps reflecting local traditions.

More remarkably, our analysis indicates that the bodies were prepared before burial in previously unknown ways. In some cases, the flexion of the limbs is so strong that it may have required an additional supporting element, such as a wrapping, which could help explain how the cadavers were placed in tight spaces. Depending on the type of wrapping (full wrapping or simply binding with ropes or bandages), the influx of sediment could have been prevented, allowing the bones to move into more hyperflexed positions as the surrounding sediment still exerted pressure on the body. The unusual pattern presented by ARA1962, unknown 3, i.e. the combination of the position of the body and the maintenance of the labile articulations of the feet, suggests that in addition to having been wrapped, this body may have been desiccated through mummification before burial. It is unclear whether the wrapping would still have been in place at that time, or whether the body, by then transformed through mummification, would have been placed in the grave unwrapped, as suggested for PSB1960, XII.

The manipulation of the body during mummification would maintain the anatomical integrity of the skeleton and ensure a desired body position. In this 
case, the pre-burial treatment would allow for the body to be curated for some time and facilitate its transport (being more contracted and significantly lighter than the fresh cadaver) while ensuring that it was buried while retaining its anatomical integrity. If our interpretation is correct, a range of insights relating to the mortuary practices of Portuguese Mesolithic communities arise, including a central concern for maintaining the integrity of the body and its physical transformation from a cadaver to a curated mummy. These practices would also underscore the significance of the burial places and the importance of bringing the dead to these locations in a manner that contained and protected the body, following principles that were culturally regulated.

Current archaeological evidence (e.g. from stable isotope analysis or the study of lithic technology) suggests that several units of hunter-gatherers occupied the Sado Valley. Autonomous groups may have buried their dead in neighbouring burial grounds (Peyroteo-Stjerna, 2016: 467). It is generally considered that in the Sado Valley shell middens, burial was concentrated in particular areas within the sites (Larsson, 1996: 30), with the graves typically placed in close proximity but with little disturbance of previous burials. Our analysis, however, shows that, while specific areas within the middens were preferred for burial, at S. Bento, the same burial space may have been reused for multiple depositions. If restricted areas were used continuously for burial, even if that meant occasionally disturbing older graves, the existence of dedicated spaces for the dead becomes all the more significant. Whether these sites were permanently settled is still debated, but we suggest that at least some individuals could have been transported to the burial ground from another location after death. Moving the dead would have been a costly endeavour; mummification before transport would have made the journey easier. Yet mummification cannot only be understood in functional terms, as transforming the appearance of the cadaver would be inscribed in a cultural understanding of handling death, and perhaps even controlling it.

Ethnographic and ethnohistoric studies in communities that practise mummification show that the preparation of the body and desiccation of the soft tissues would have required the active involvement of group members tending to the body over at least a few days or weeks to several months (Beckett et al., 2017; Beckett, 2020). Our taphonomic mummification experiment confirms that a range of preparative and curative actions are required for weeks or months to ensure desiccation of the body. Halting or slowing the decomposition processes and desiccation of the soft tissues, i.e. natural mummification, occurs when the loss of water from the body (drying) is more rapid than enzyme activity. Hot and dry conditions combined with continuous air flow are favourable for such natural desiccation. Additional human actions contributing to preventing soft tissue decomposition and assisting desiccation include the construction of a platform or structure to elevate the body to allow liquids to drain; a hut or roof to protect the body from the rain; and cleaning the body and rubbing it with ointments and plant extracts to ward off insects and perhaps retard bacterial activity. Bodies are sometimes wrapped in textiles during desiccation, to help wick off fluids, and may be wrapped or kept in containers after mummification is complete. Draining of fluids and even disembowelment to stop bacterial decay can be induced by inserting sticks into the anus and other parts of the body (Beckett et al., 2017; Valentin \& Sand, 2019; Beckett, 2020; Carascal et al., 2021). Keeping a fire 
close to the body, such as in the smoking huts constructed by the Anga in Papua New Guinea and the Ibaloi in the northern Philippines, accelerates the process of desiccation and wards off insects through heat and smoke (Beckett et al., 2011; Carascal et al., 2021).

In temperate Mediterranean climates with long hot summers, as in southern Portugal, the earliest signs of putrefaction of a body exposed to the air can become evident just half a day after death (Pinheiro, 2006: 97). While these conditions can accelerate decomposition, they can also facilitate natural mummification. Wind and heat would be important agents, but the process would also require active human engagement. To produce the observed patterns, the body would have been trussed and probably placed on an elevated structure, allowing the decomposition fluids to drain away from further contact with the body. It is also possible that the transformation would have included the use of fire, which would also have needed attention. Over time, the bandages would have been tightened (trussing) to support and retain the anatomical integrity of the deceased while increasing the bilateral pressure on the body and the flexion of the limbs. In short, the process involves a complex and lasting engagement with the cadaver, an engagement that would have been visible to the community, and a significant part of its mortuary practices.

Pre-burial treatments such as desiccation through mummification have not been suggested for the Mesolithic before, but similarities with other Mesolithic burial sites exist in the Sado Valley, such as at Vale de Romeiras, where the cadavers were frequently compressed and laid in highly hyperflexed positions. Here, the extremely constrained and hyperflexed position of individual 23 is particularly striking: when excavated, the bundled skeleton occupied a small area of $49 \times 32$ $\mathrm{cm}$, resembling a square burial position (Peyroteo-Stjerna, 2016: 332-34).

The fact that mummification in Mesolithic Portugal has not been proposed before may be owed to research biases and expectations. Evidence for mummification practices in prehistoric Britain, including histotaphonomic (taphonomic processes at the microstructural scale), radiocarbon, and archaeothanatological evidence, has revealed that, contrary to traditional expectations, practices of retention of the dead including mummification may have been widespread (Parker Pearson et al., 2005; Booth et al., 2015; Smith et al., 2016). In the European Mesolithic, archaeological patterns consistent with mummification, such as those seen in ARA1962, unknown 3 , have so far not resulted in the same interpretation, even when extreme flexion and lack of movement of bones cannot be explained. Hence, comparative and experimental archaeothanatological studies are a valuable tool to investigate the processes of decomposition. It would be desirable to follow up our archaeothanatological observations with complementary histological analyses of the bones to assess the level of bacterial bioerosion (see Parker Pearson et al., 2005; Booth et al., 2015; Smith et al., 2016), but, because the excavation context number attributed to unknown 3 is uncertain, we cannot identify the bones in the collection. Being a single case, it is difficult to say whether it represents an exceptional or a more common practice. It would also be valuable to revisit the analysis of other potential cases such as PSB1960, XII, the possible cases suggested from Vale de Romeiras, and the Mesolithic burial F528 recently identified in Champigny, France (Garmond \& Binder, 2020) with the same combination of archaeothanatological analysis and knowledge gained from experimental taphonomy. Future excavations using an archaeothanatological protocol and 
considering the possibility of mummification may also provide new robust evidence for pre-burial practices in prehistory.

\section{Conclusion}

The newly rediscovered photographs of burials at Arapouco and Poças de S. Bento and their analysis, informed by archaeothanatology and experimental taphonomy, allows us to add information on a series of burials of the Portuguese Mesolithic. These burials generally conform to the pattern characteristic of the mortuary practices known for these hunter-gatherer communities, but aspects of the treatment of the body, including its transformation and curation before burial, are new elements. New insights into the use of burial places, such as a very tight clustering of burials, and the proposed cases of mummification and subsequent interment of hyperflexed, intact bodies highlight the significance of both the body and the burial place in the wider hunter-gatherer landscape of south-western Portugal.

\section{ACKNOWLEDgMenTs}

We thank the National Museum of Archaeology in Lisbon for research permits, access to the collections, and continuous support; José Paulo Ruas for the photographs of site plans and human remains in paraffin blocks; the Sado-Meso Research Team in 2010-2017 for access to the shell midden sites and fieldwork opportunities; Denis Bouquin for references and discussion of comparative material in Champigny, France; Aaron Stutz for the English revision and comments on the manuscript. This work was supported by the VINNOVA-funded 'MSCA Seal of Excellence' postdoctoral research project 'THANATOS' (Grant number 201905211). The taphonomic experiments were supported by the ERC Synergy programme (Grant number 319209), the Leiden University Fund Byvanck (Grant number 5604/30-4-2015/ Byvanck), and the 2017 Royal Netherlands Academy of Arts and Sciences (KNAW) 'National Postdoc Prize' awarded to Hayley Louise Mickleburgh. We also thank the Forensic Anthropology Center at Texas State, Texas State University, San Marcos, TX, for supporting the taphonomic experiments, and the body donors and their next-of-kin for their valuable gift to science.

\section{Supplementary Material}

To view supplementary material for this article, please visit https://doi.org/10.1017/ eaa.2022.3.

\section{REFERENCES}

Arias, P., Diniz, M., Araújo, A.C., Armendariz, Á. \& Teira, L.C. 2021. New Perspectives on the Mesolithic of the Sado Valley (Southern Portugal): Preliminary Results of the SADO MESO Project. In: D. Borić, D. Antonović \& B. Mihailović, eds. Foraging Assemblages. Belgrade \& New York: Serbian Archaeological Society, The Italian Academy for Advanced Studies in America, Columbia University, pp. 274-80.

Arnaud, J.M. 1989. The Mesolithic Communities of the Sado Valley, Portugal, in their Ecological Setting. In: C. Bonsall, ed. The Mesolithic in Europe: Papers Presented at the Third International Symposium. Edinburgh: John Donald, pp. 614-31.

Beckett, R.G. 2020. Smoked Bodies of Papua New Guinea. In: D.H. Shin \& R. Bianucci, eds. The Handbook of Mummy Studies: Nerw Frontiers in Scientific and Cultural Perspectives. Singapore: Springer, pp. 1-26. https://doi.org/10.1007/978981-15-3354-9_34

Beckett, R.G., Lohmann, U. \& Bernstein, J. 2011. A Field Report on the Mummification 
Practices of the Anga of Koke Village, Central Highlands, Papua New Guinea. Yearbook of Mummy Studies, 1: 11-17.

Beckett, R.G., Conlogue, G.J., Abinion, O.V., Salvador-Amores, A. \& PiombinoMascali, D. 2017. Human Mummification Practices Among the Ibaloy of Kabayan, North Luzon, the Philippines. Papers on Anthropology, 26: 24-37.

Booth, T.J., Chamberlain, A.T. \& Parker Pearson, M. 2015. Mummification in Bronze Age Britain. Antiquity, 89: 115573. https://doi.org/10.15184/aqy.2015.111

Carascal, M.B., Fontanilla, I.K.C. \& De Ungria, M.C.A. 2021. The Ibaloi Fire Mummies: The Art and Science of Mummification in the Philippines. Anthropological Science, 129: 197-202. https://doi.org/10.1537/ase.210422

Cardoso, J.L. 2013. Elogio do Professor Manuel Farinha dos Santos (1921-2001). Lisboa: Academia Portuguesa da História.

Cunha, E. \& Umbelino, C. 1997. Abordagem antropológica das comunidades mesolíticas dos Concheiros do Sado. O Arqueólogo Português, 13-15: 161-79.

Cunha, E. \& Umbelino, C. 2001. Mesolithic People from Portugal: An Approach to Sado Osteological Series. Anthropologie, 39: 125-32.

Diniz, M., Arias, P., Teira, L., Araújo, A., Cubas, M., Neves, M., et al. 2014. Relatório de progresso. Os últimos caçadores-recolectores e os primeiros grupos agro-pastoris no vale do Sado. Estudo arqueológico num contexto regional (SADO-MESO): Poças de S. Bento, Arapouco e Vale de Romeiras (Alcácer do Sal). Ano 4, 2013. Unpublished report. Lisboa: DireçãoGeral do Património Cultural.

Duday, H. 2009. The Archaeology of the Dead: Lectures in Archaeothanatology. Oxford: Oxbow Books. http://dx.doi.org/10.2307/j. ctt1cd0pkv

Duday, H., Courtaud, P., Crubezy, E., Sellier, P. \& Tillier, A. 1990. L'anthropologie « de terrain »: reconnaissance et interprétation des gestes funéraires. Bulletins et Mémoires de la Société d'antbropologie de Paris, 2: 29-50. http://dx.doi.org/10.3406/bmsap.1990.1740

Garmond, N. \& Binder, S. 2020. Champigny: Au-dessus des Caves, le Mont Sain-Pierre et le Pré de l'Isle. Marne, Grand Est. Rapport final d'opération. Vol. 1, Prébistoire. Reims:
Service Archéologique de la Communauté Urbaine du Grand Reims.

Hoogland, M.L.P. \& Hofman, C.L. 2013. From Corpse Taphonomy to Mortuary Behavior in the Caribbean: A Case Study from the Lesser Antilles. In: W.F. Keegan, C.L. Hofman \& R. Rodríguez Ramos, eds. The Oxford Handbook of Caribbean Archaeology. Oxford: Oxford University Press, pp. 453-70. https://doi.org/10.1093/ oxfordhb/9780195392302.013.0126

Hoogland, M.L.P., Romon, T. \& Brasselet, P. 2001. Excavations at the Site of Anse à la Gourde, Guadeloupe: Troumassoid Burial Practices. Proceedings of the 18th International Congress for Caribbean Archaeology, 18: 173-78.

Larsson, L. 1996. Late Atlantic Settlement in Southern Portugal: Results of an Excavation of a Mesolithic Shell Midden by the River Sado. Current Swedish Archaeology, 4: 123-39. https://doi.org/10. 37718/CSA.1996.08

López-Dóriga, I., Diniz, M. \& Arias, P. 2016. Macrobotanical Remains and Shell-Midden Formation Processes, Are They Related? The Case of Poças de São Bento (Portugal). Archaeological and Anthropological Sciences, 11: 469-81. https://doi.org/10.1007/ s12520-016-0429-6

Maureille, B. \& Sellier, P. 1996. Dislocation en ordre paradoxal, momification et décomposition: observations et hypothèses. Bulletins et Mémoires de la Société d'Anthropologie de Paris, 8: 13-327. https:// doi.org/10.3406/bmsap.1996.2451

Nilsson Stutz, L. 2003. A Taphonomy of Ritual Practice: A 'Field'-Anthropological Study of Late Mesolithic Burials. In: L. Larsson, H. Kindgren, K. Knutsson, D. Loeffler \& A. Åkerlund, eds. Mesolitbic on the Move: Papers Presented at the Sixth International Conference on the Mesolithic in Europe, Stockholm 2000. Oxford: Oxbow Books, pp. 527-35.

Nilsson Stutz, L. 2009. A Baltic Way of Death? A Tentative Exploration of Identity in Mesolithic Cemetery Practices. In: Å.M. Larsson \& L. Papmehl-Dufay, eds. Uniting Sea II: Stone Age Societies in the Baltic Sea Region. Uppsala: Uppsala University, pp. 127-44.

Parker Pearson, M., Chamberlain, A., Craig, O., Marshall, P., Mulville, J., Smith, H., et al. 2005. Evidence for Mummification 
in Bronze Age Britain. Antiquity, 79: 529-46. https://doi.org/10.1017/ S0003598X00114486

Peyroteo-Stjerna, R. 2016. On Death in the Mesolithic: Or the Mortuary Practices of the Last Hunter-Gatherers of the South-Western Iberian Peninsula, 7th-6th Millennium BCE. Uppsala: Uppsala University.

Peyroteo-Stjerna, R. 2021. Chronology of the Burial Activity of the Last Hunter-Gatherers in the Southwestern Iberian Peninsula, Portugal. Radiocarbon, 63: 265-99. https:// doi.org/10.1017/RDC.2020.100

Pinheiro, J. 2006. Decay Process of a Cadaver. In: A. Schmitt, E. Cunha \& P. Pinheiro, eds. Forensic Anthropology and Medicine: Complementary Sciences from Recovery to Cause of Death. Totowa (NJ): Humana Press, pp. 85-116. https://doi.org/10. 1007/978-1-59745-099-7_5

Santos, M.F., Soares, J. \& Silva, C.T. 1974. O concheiro epipaleolítico do Cabeço do $\mathrm{Pez}$ (Vale do Sado, Torrão). Primeira notícia. In: Actas do III Congresso Nacional de Arqueologia, 1973. Porto: Junta Nacional de Educação, pp. 173-90.

Smith, M.J., Allen, M.J., Delbarre, G., Booth, T., Cheetham, P., Bailey, L., et al. 2016. Holding on to the Past: Southern British Evidence for Mummification and Retention of the Dead in the Chalcolithic and Bronze Age. Journal of Archaeological Science: Reports, 10: 744-56. https://doi. org/10.1016/j.jasrep.2016.05.034

Tõrv, M. 2018. Persistent Practices: A MultiDisciplinary Study of Hunter-Gatherer Mortuary Remains from c. 6500-2600 cal $B C$, Estonia. Kiel/Hamburg: Wachholtz \& Murmann.

Valentin, F. \& Sand, C. 2019. Mummification of the Human Body as a Vector of Social Link: The Case of Faténaoué (New Caledonia). In: M. Leclerc \& J. Flexner, eds. Archaeologies of Island Melanesia: Current Approaches to Landscapes, Exchange and Practice. Canberra: ANU Press, pp. 165-78. https://doi.org/10.22459/TA51.2019.11

\section{Biographical Notes}

Rita Peyroteo-Stjerna is a bioarchaeologist specialized in mortuary archaeology and trained in archaeothanatology, ancient DNA, radiocarbon and isotopes, and archaeological research in museum collections. She has worked with archaeological museum collections since 2011 in Europe, Africa, and Southeast Asia. Her PhD from Uppsala University considered the role of mortuary practices among Mesolithic hunter-gatherers. She has been a researcher at the Human Evolution Research Program at the Evolutionary Biology Centre in Uppsala since 2016, where she developed protocols for contamination-free sampling of human bones with minimal impact on museum collections. She has published on Holocene hunter-gatherers in Iberia and is currently working in several interdisciplinary projects in Europe, Asia, and Africa.

Address: Human Evolution, Department of Organismal Biology, Uppsala University, Norbyvägen 18C, 75236 Uppsala, Sweden, and UNIARQ2 Centro de Arqueologia da Universidade de Lisboa, Portugal. [email: rita.peyroteo.stjerna@ebc.uu.se]. ORCID: https://orcid.org/0000-0002-3309-474

Liv Nilsson Stutz is a professor of archaeology at Linnaeus University, Sweden. She is a bioarchaeologist specialized in mortuary practices and, since the 1990s, has worked with archaeothanatology and how it can be integrated with archaeological theory. Trained in biological anthropology and archaeology, she has conducted fieldwork in France, Latvia, and Jordan, and has published broadly on the archaeology of death, ritual practice, the body, and Mesolithic mortuary practices, as well as archaeological method and theory, interdisciplinary archaeology, and the repatriation and reburial of human remains. She currently leads the Archaeothanatology Working Group, and has started the 'Ethical Entanglements' project on the 
ethics of curating and researching human remains in museums.

Address: Department of Cultural Sciences, Linnaeus University, 35195 Växjö, Sweden. [email: liv.nilssonstutz@1nu.se]. ORCID: https://orcid.org/0000-0002-0575-7075

Hayley Louise Mickleburgh is a forensic archaeologist, bioarchaeologist, and 3D modelling and animation specialist. Her research includes mortuary archaeology, Caribbean archaeology, and forensic taphonomy; she is interested in exploring the use of experimental forensic taphonomy to better understand past human burials and mortuary behaviour, conducting human decomposition experiments at the Forensic Anthropology Center at Texas State University since 2015. She is listed in the National Expertise databank of the Dutch Police Academy and is currently president of the Dutch Association for Physical Anthropology. She has excavated in the Caribbean and undertaken bioarchaeological and mortuary analysis of precolonial Caribbean skeletal assemblages. Her current research focuses on mass graves, and on the ethics of curating and researching human remains in museums.

Address: Department of Cultural Sciences, Linnaeus University, 35195 Växjö,
Sweden, and Forensic Anthropology Center, Texas State University, San Marcos, Texas, USA. [email: hayley.mickleburgh@1nu.se]. ORCID: https://orcid. org/0000-0001-9326-8097

João Luís Cardoso is a professor at Universidade Aberta (Open University) in Portugal since 2005, where he is currently vice-rector and president of the Scientific Council. His scientific activity is embodied by more than 700 scientific articles published in Portugal and in international journals, focusing on various themes, mainly prehistoric but also on the history of archaeology and zooarchaeology. $\mathrm{He}$ is the author of some twenty books, some receiving several distinctions. $\mathrm{He}$ is a member of the Royal Academy of History (Madrid) and the German Archaeological Institute (Berlin) and, among others, the Lisbon Academy of Sciences and the Portuguese Academy of History, where he was its first vice president.

Address: Universidade Aberta, Palácio Ceia, Rua da Escola Politécnica, no. 141-147, 1269-001 Lisboa, Portugal, Centre of Archaeological Studies, Oeiras Municipal Council, Portugal, and ICArEHB, Universidade do Algarve, Faro, Portugal. [email: cardoso18@netvisao.pt]. ORCID: https://orcid.org/0000-0003-2234-2266

\section{La momification au Mésolithique : une approche novatrice basée sur d'anciens clichés révèle des pratiques funéraires insoupçonnées dans la vallée du Sado au Portugal}

Une série de photos récemment redécouvertes, illustrant les sépultures de treize individus ensevelis dans les amas coquilliers mésolithiques de Poças de S. Bento et d'Arapouco fouillés en 1960 et en 1962 dans la vallée du Sado au Portugal, démontre le potentiel d'une réévaluation d'anciennes archives avec de nouvelles méthodes. L'examen des clichés, dans une perspective archéothanatologique et étayés par des recherches expérimentales en taphonomie, a révélé certains détails concernant le traitement des cadavres et offert de nouvelles perspectives sur des lieux de sépulture. Certains cadavres auraient été momifiés, un phénomène que les auteurs associent à la mise en valeur et au transport des défunts et qui souligne 
limportance du corps et du lieu de sépulture pendant le Mésolithique dans le sud du Portugal. Translation by Madeleine Hummler

Mots-clés: Mésolithique, sépultures, pratiques funéraires avant ensevelissement, archéothanatologie, momification, taphonomie expérimentale

\section{Mumifizierung im Mesolithikum: neue Ansätze aufgrund von alten Fotografien dokumentieren bisher unbekannte Bestattungsbräuche im Sadotal in Portugal}

Letztlich wiederentdeckte Fotos von dreizehn Individuen, welche in den mesolithischen Muschelhäufen von Poças de S. Bento and Arapouco im portugiesischen Sadotal in den Jabren 1960 und 1962 ausgegraben wurden, zeigen das Potenzial einer Neubewertung von Archivalien mit neuen Methoden. Die Auswertung der Bilder, aus einer archäothanatologischen Perspektive gesehen und von experimentellen taphonomischen Untersuchungen unterstützt, hat Aspekte der Behandlung der Leichen bestätigt und neue Einblicke in die Benutzung von Begräbnisstätten geliefert. Die Ergebnisse deuten auf eine mögliche Mumifizierung der Leichen, was vielleicht mit deren Erhaltung und Transport verbunden ist und die Bedeutung des physischen Körpers der Toten sowie der Bestattungsstätten im südportugiesischen Mesolitbikum betont. Translation by Madeleine Hummler

Stichworte: Mesolithikum, Bestattungen, Behandlung bevor Grablegung, Archäothanatologie, Mumifizierung, experimentelle Taphonomie 